DOI: 10.2478/rae-2021-0008 Review of Artistic Education no. $212021 \quad 56-70$

\title{
8. AN ANALYSIS OF THE VOICE ASSEMBLIES FROM THE OPERA LA CENERENTOLA BY GIOACHINO ROSSINI
}

\author{
Cristina Simionescu Fântână ${ }^{36}$
}

\begin{abstract}
A musical inspiration, the opera La Cenerentola by Gioachino Rossini offers a wealth of examples of how to capitalize on the vocal and musical potential offered by the opera show. We aim to analyze vocal ensembles and to emphasize their musical and dramaturgical. realization.
\end{abstract}

Key words: opera, vocal ensembles, comic

\section{Introduction}

At the beginning of the 19th century, the ends of scenes were the moment when all the protagonists of the show were on the stage to express their thoughts and experiences, without having a directorial or theatrical role. The rhythmic and melodic diversity and voice virtuosity are played at this stage end using small note values, fast tempo, and syllabic song.

\section{The duet Clorinda-Tisbe and vocal trio}

The duet Clorinda-Tisbe from the beginning of the work presents a scene from the everyday life of the sisters who do not count on self-assessing (superlatively) their qualities. The scene is explained as follows: Antica sala terrena nel Castelo del Barone, con cinque porte; a destra camino, tavolino con specchio, cestello con fiori e sedie. Clorinda provando uno sciassé; Tisbe acconciando un fiore ora alla fronte, ora al petto; Cenerentola soffiando con un manticetto al camino per far bollire un cuccumo di caffe ${ }^{37}$.

The orchestral exposition (Allegro con brio) describes the slight state of agitation and the rivalry between the sisters. The contrast of the melodic cells (the first - sixteenths legato, the second - eights staccato) suggests the pride and whims of girls that changes as quickly as the shade (forte - piano). Clorinda is first showing her qualities proudly claiming that no one can dance a lighter and more elegant sciassé than she is. The bold over-reaching character of the girl results perfectly clear, amplifying with each added sound results from the sprint rhythm and the ascending song (the arpeggio in G Major in the second overturning).

E.g., 1 (G. Rossini - La Cenerentola, G. Ricordi \& C. Editori - Stampatori, Milano, 1997, act I, Introduzione, p. 11, ms. 18-25):

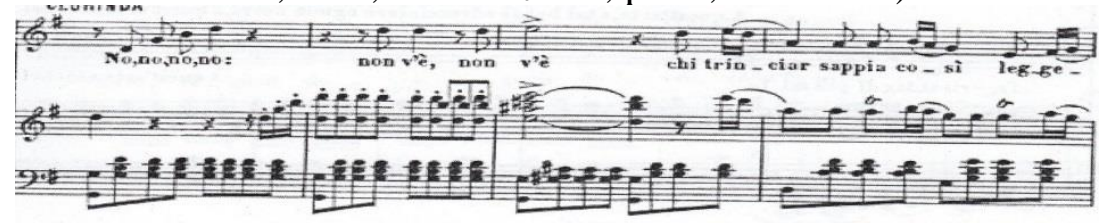

\footnotetext{
${ }^{36}$ Associate Professor PhD. habil., "George Enescu” National University of Arts, Iaşi, România, email: crystina.simionescu@yahoo.com

${ }^{37}$ The old room in the Baron's castle with five doors; on the right side of the fireplace, a mirror table, a basket of flowers and chairs. Chlorinda studies a sciasé; Tisbe arranges herself with a flower, placing it from the forehead to the chest; Cinderella blows in the stove to bring a boil coffee kettle (t.a. Cr.S.A.)
} 


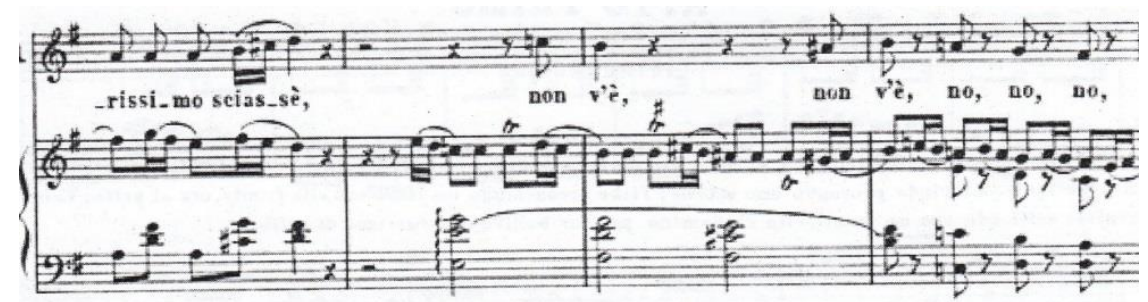

The sisters' smugness turns into a musical triumph at the end of this short duet (unison), proving preeminence toward all the others around: A quest'arte, a tal beltà sdrucciolare ognun dovrà ${ }^{38}$. It should be noted that Tisbe (mezzosoprano) sings in the major third against Chlorinda (soprano), this reversal being used by the composer to highlight the rivalry for the achievement of life ideals. We will not see dynamic indications, but we see a series of accents that highlight the character of the sisters. The accompaniment is made up of chords (eights followed by eight breaks) which serve as harmonic support.

E.g., 2 (G. Rossini - La Cenerentola, G. Ricordi \& C. Editors - Stampatori, Milano, 1997, act I, Introduzione, p. 12, ms. 35-37):

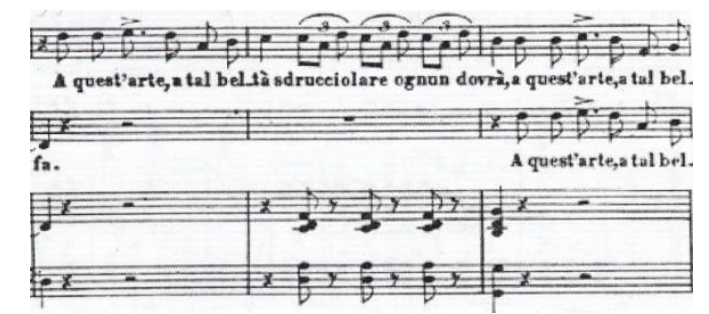

The rivalry of girls is in progress and if Tisbe plays an ascending arpeggio starting from the $D 1$, immediately Clorinda plays an arpeggio on $G 1$. The emphasis on the word $B$ (simultaneously played, forte) shows for the first time an agreement between the sisters, both of which appreciate their qualities and knowledge as worthy of fame.

E.g., 3 (G. Rossini - La Cenerentola, G. Ricordi \& C. Editors - Stampatori, Milano, 1997, act I, Introduzione, p. 13, ms. 39-45):

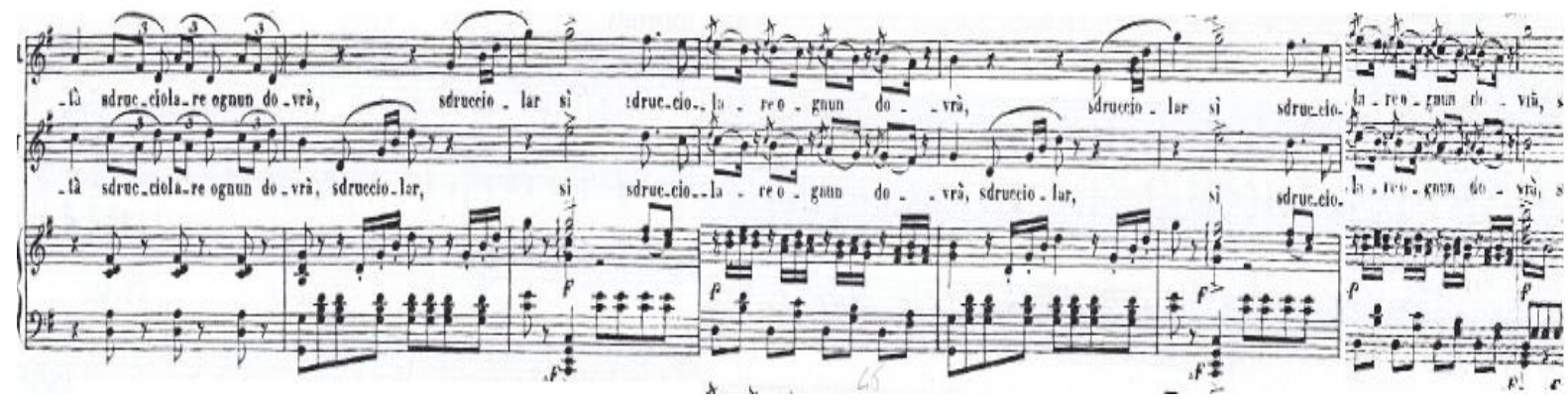

The Coda echoes in a brilliant $G$ Major, in forte, which renders the smugness, the safety and the advantage of preparation, skills and beauty that characterizes them, facilitating their ability to seize anyone. The stupidity and helplessness of girls are translated by Rossini by using a small number of tones that the melodic line passes through. Written in the tone of $G$ Major, the duet modulates once to D Major (the tone of dominance), and finally to D Minor (the homonym of dominance), the tone in which the vocal trio of the sisters will begin.

Angelina's song is built in contrast to the stepsisters' condition both by tone ( $D$ minor) and by the educational background (Andantino), as well as by the rhythmic character and the message transmitted. Angelina's melancholy and

${ }^{38}$ Everyone should aspire to so much art and beauty (t.a. Cr.S.A.) 
annoyance are described by broken melodic lines of a swinging character, right from the start of the vocal trio.

E.g., 4 (G. Rossini - La Cenerentola, G. Ricordi \& C. Editors - Stampatori, Milano, 1997, act I, Introduzione, p. 14, ms. 55-63):

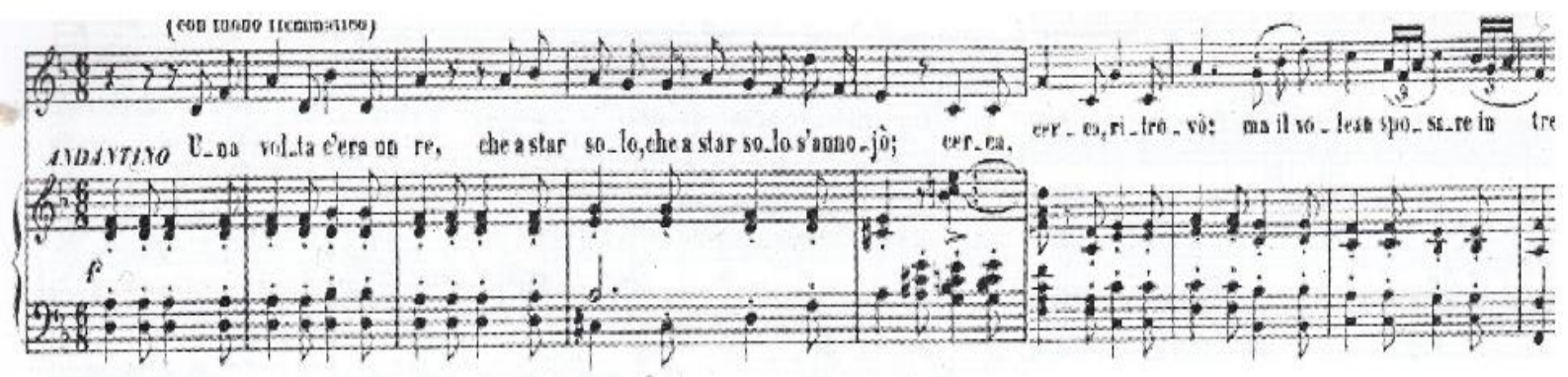

The 6/8 measure finds its swinging balance in the orchestral accompaniment by repeating the quarter followed by the eighth, as a perpetuum mobile. The rhythm of the voice line is perfectly matched to this accompanying structure from which we will discover Angelina's grieving and dreamy character. Sometimes the accompaniment takes on a solistic role (repeating Angelina's last melodic reason), sometimes the voice is doubled by the orchestra in the accute register.

The story in the girl's song expresses the hope that one day a person would discover her l'innocenza e la bonta ${ }^{39}$ beyond her ragged clothes, and her fate will change. This story annoys the two snotty girls, who say that their selected beauty and education have more value than the purity and kindness of Cinderella. The malicious nature of the sisters is rendered by Rossini by the sudden change of the tempo (Allegro) and measure (4/4), the distinction between these and Cenerentola being painted by the construction of the melodic line: if Angelina has phrases with a swinging character and broken walk, the sisters' sentences come from the acute register, with repeated sounds or with gradual, descending movement.

E.g., 5 (G. Rossini - La Cenerentola, G. Ricordi \& C. Editors - Stampatori, Milano, 1997, act I, Introduzione, p. 14, ms. 75-79):

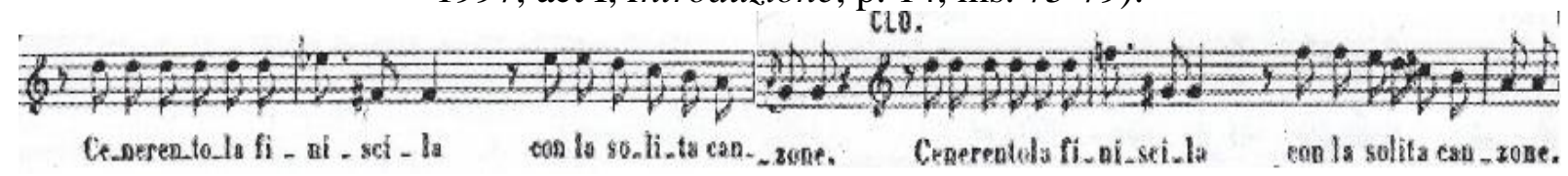

For highlighting the different characters of the three girls, Rossini uses the values of sixteenths for Clorinda and Tisbe, and for Angelina eights or higher values, or in acompaniment (double-dotted values and the tunic structures that duplicate the melodic line of Tisbe and Clorinda contrast with long notes and overlapping voice structures in the line of Angelina).

E.g., 6 (G. Rossini - La Cenerentola, G. Ricordi \& C. Editors - Stampatori, Milano,

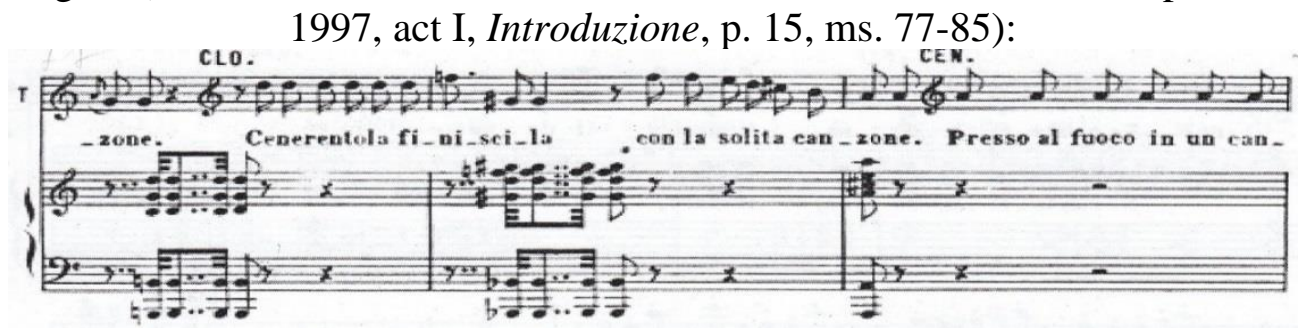

\footnotetext{
${ }^{39}$ Innocence and goodness. (t.a. Cr.S.A.)
} 


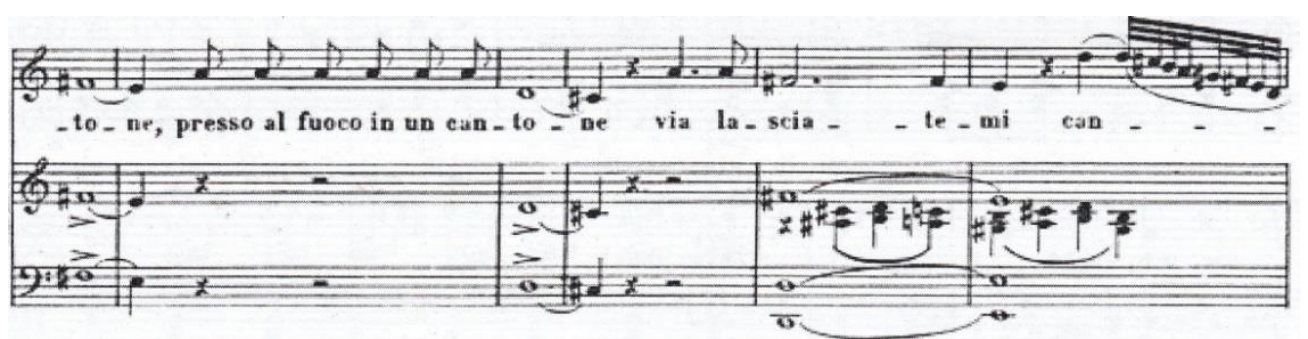

Angelina's cadence (ascending-descending melodic movement, on a wide palette, started from sound $A$ in the low octave until G2) is also her first sign of revolt, because she demands nothing more than to be allowed to sing her hopegiving song. The end of the tercet is anticipated by a long break with crown, Angelina resumes her song (în 6/8, Andantino), but she is suddenly interrupted again by Clorinda and Tisbe who imitate her in the same rhythm, and then return to their dotted line (in accute) until the quarrel is broken by knocking at the door.

\section{The Quartet and the end of the first act}

The following Quartet includes an instrumental introduction (4/4, Moderato, in piano) describing the appearance of Alidoro (as beggar): a complex melodic line with several sound and rhythmic planes that you will find in the soloist line. Alidoro's replicas are played in piano, unlike the answers of Clorinda and Tisbe (which drive him out of the house) - from crescendo until forte.

E.g., 7 (G. Rossini - La Cenerentola, G. Ricordi \& C. Editors - Stampatori, Milano, 1997, act I, p. 16, ms. 110-113):

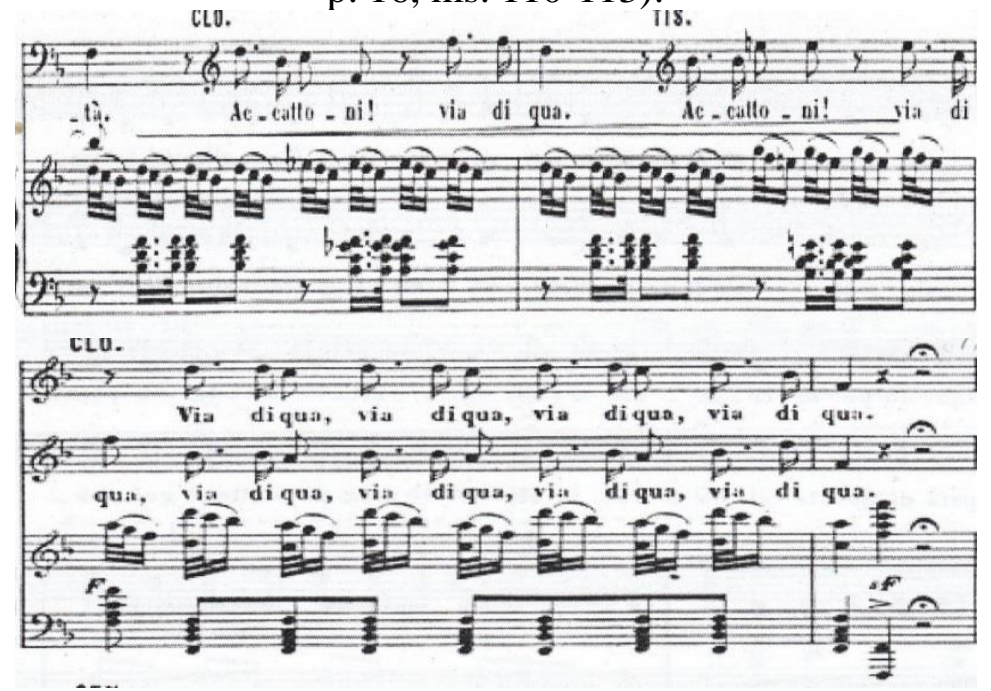

The difference between the brutal behavior of sisters and the gentleness and kindness of Cenerentola is noted by the crown (gradual, downward movement); Angelina versa una tazza di caffè, e la dà con un pane ad Alidoro coprendolo dalle sorelle $e^{40}$ and offers the old man Questo po' di colazione" ${ }^{\prime 1}$. A melodic ascending line (piano) describes the joy of Alidoro, who is sure that he found the right person for the prince's hand. The Quartet created renders very expressively the feelings of the characters: the sisters hope that they will awaken sweet passions (unison), Alidoro thanked Cenerentola for her gesture, telling her that one day God would repay her; Angelina, disinterested in the reward, wants only not to be discovered by her sisters.

\footnotetext{
${ }^{40}$ Pours a cup of coffee and passes it to Alidoro with bread, covering him for not to be discovered by her sisters (t.a. Cr.S.A.)

${ }^{41}$ Some breakfast (t.a. Cr.S.A.)
} 
E.g., 8 (G. Rossini - La Cenerentola, G. Ricordi \& C. Editors - Stampatori, Milano, 1997, act I, p. 18, ms. 123-127):

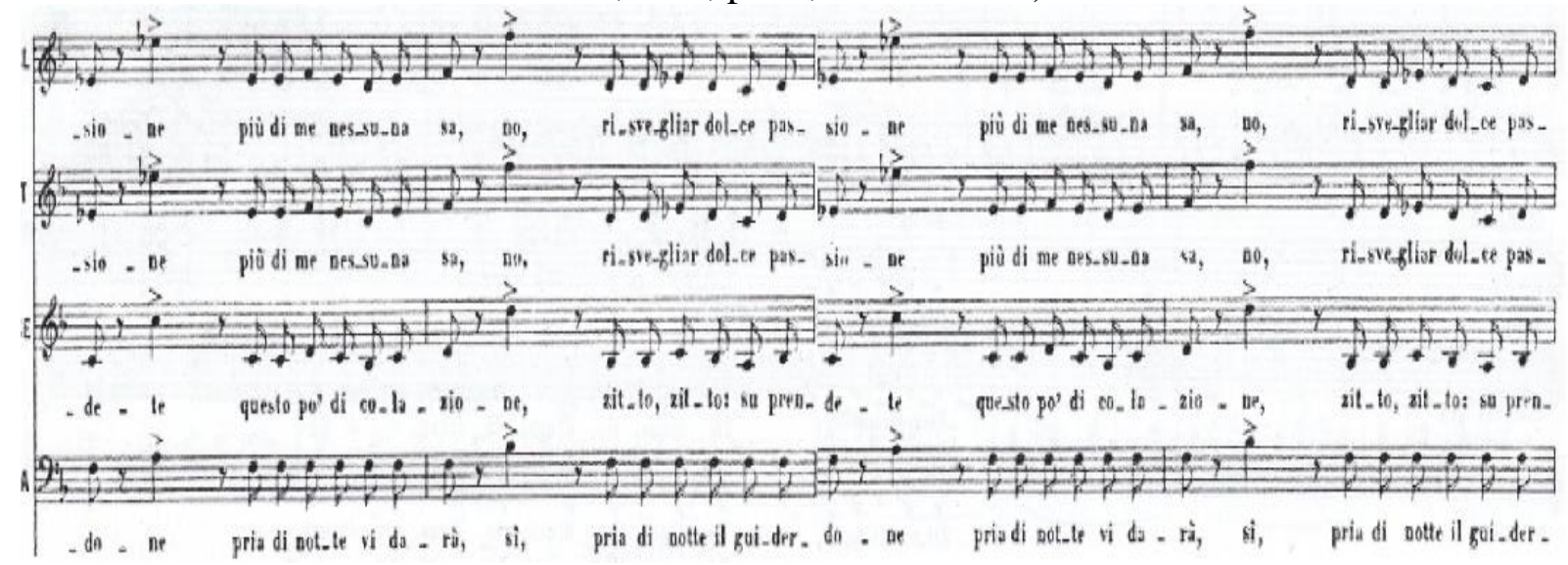

The differentiation in the emotional states of the characters is made during the following musical period: the sisters sing (at third interval) hoping that they will find the person who will appreciate their qualities; Angelina (a melodic line with equal and dotted sixteenths) expresses indignation against the superficiality of the two: Ah, non reggo alla passione. Che crudel fatalità! ${ }^{42}$; Alidoro promises a generous reward for the good acts of Cinderella (short interventions), clearly distinguishing itself from the troubled musical speech of the sisters, which shows indolence and selfishness.

The short rhythmic motives made up of repeated notes and small intervals (third and quartet) reflect the wickedness and wrath of her sisters toward the dirty old beggar not leaving from their home (Ma che vedo! Ancora lì! Anche un pane? anche il caffè $\left.{ }^{43}\right)$, the same hideous character, their anger spilling over Angelina, whom they assault with blows. Alidoro aways them on a melodic line (values of sixteenths, arpeggio from tonic in $G$ minor, second overturning) that shows the dismay of the character in a situation he did not foresee.

The scandal suddenly stops following the appearance of the men's choir (the princely guard) announcing the arrival of the prince looking for his future wife. Clorinda is the first interrupting the speech of the choir with a short intervention that reveals curiosity (ascending melodic movement) and the impatience with which the prince is awaited (eigth with point followed by sixteenth). The sisters move from euphoria to maximum agitation to be as arranged as possible at the time of the arrival of the prince; they put Cenerentola on a real marathon from one to the other, to satisfy all their whims. Irritated by all the agitation created and full of grief, Cinderella imitates them with a musical phrase that becomes funny with the faithful reproduction of the sisters' twitches.

Rossini proves to be a forerunner of Giuseppe Verdi (the famous quartet of Rigoletto): Clorinda and Tisbe show their selfishness by saying, in turn: son più bella e vo' trionfar ${ }^{44}$, and here, because of the desire to highlight the identical nature of the two sisters, Rossini makes a short-range omophony in the serious register. Alidoro is permanently in time trial with the melodic line of the sisters, unheeded by anyone, who stands aside, observes and analyzes the whole scene,

\footnotetext{
${ }^{42}$ Ah! I can't think of passion. How cruel fate! (t.a. Cr.S.A.)

${ }^{43}$ But what do I see! He is still there! And bread? And coffee? (t.a. Cr.S.A.)

${ }^{44}$ I'm the most beautiful and I want to win (t.a. Cr.S.A.)
} 
drawing some conclusions on the ending: nel cervello una fucina sta le pazze a martellar; ma già pronta è la ruina, voglio ridere e schiattar ${ }^{45}$.

The melodic line of Cenerentola expresses oppression and suffering: Questo e proprio uno strapazzo! Mi volete far crepar ${ }^{46}$, clearly detaching from the background of the other voices. The orchestra is accompanying on a $G$ pedal in the low register, and in the medium to acute register doubles the soloistic voices. The tension is dynamically accumulating from piano through a gradually crescendo to fortissimo, all the voices intonating omophonically nel cervello una fucina. The composer proves his compositional art by using variations and taking over the melodic line from one group of soloists to another (from Tisbe - Clorinda to Cenerentola - Alidoro).

The end of the scene brings to the foreground the omophonic structure in which, on a monodic orchestral accompaniment, the voices of the soloists expose the aparte vertically, while the text reveals the feelings of the characters. Thus, in the case of sisters, we are talking about selfishness and vanity, Cenerentola deplores her fate, Alidoro realizes that he will have great fun from the stupidity and vanity of the two, and the chorus of coutiers hopes that kindness will triumph and the girl with the greatest virtues will gain the love of the prince.

The dynamics of this fragment is described by the melodic course, the meaning of words and the accents of the orchestral melodic line. We see that from measure 194 to the end of the assembly, forte is the predominant nuance (at that time, the ends were a culmination of previous actions from a dramatic and musical point of view). The accompaniament is quite complex, with transitions from two independant voices to three and even four, anticipating the rhytmic and melodic cells in the dialogue Clorinda - Tisbe (which will appear in the melody of Cenerentola); orchestra ( $G$ pedal) supports the voices on distinct levels: one based on rhytmic and melodic cells with an ascending motion (that doubles the voice of Cenerentola) and another that doubles the sisters' interventions on the words of Don Ramiro ( $G$ note, focusing on the second and third beats). The instrumental Codetta keeps a single soloistic line from all the previous fragment - of Angelina (in the upper voice) as a remember, but also as a anticipation of the development of the action.

E.g., 9 (G. Rossini - La Cenerentola, G. Ricordi \& C. Editors - Stampatori, Milano, 1997, act I, p. 45, ms. 369-378):

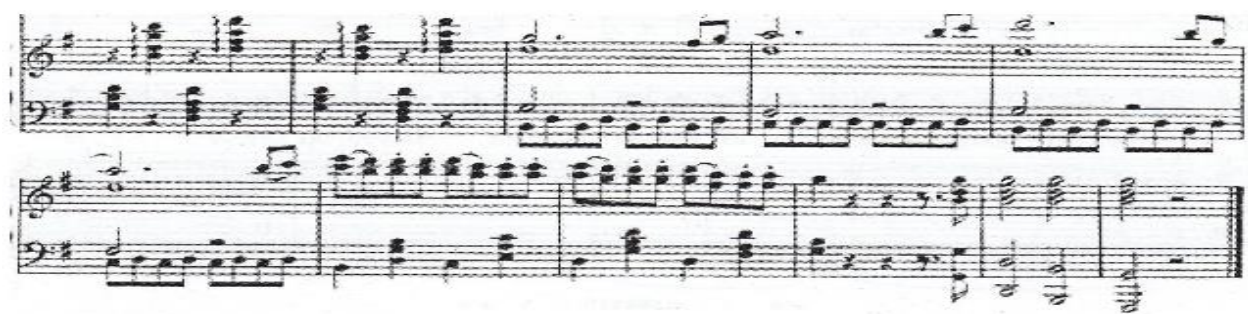

Dandini (the false prince) makes his magistral appearance into a carriage accompanied by courtiers on a triumphal orchestra introduction. The rude manner in which he addresses the sisters does not make them outrageous as long as they have been told that there is a prince before them. In the pompous Cavatina Come

\footnotetext{
${ }^{45} \mathrm{~A}$ bomb stands to explode in the head of the crazy girls, their destruction is already ready, I want to laugh till I can no longer (t.a. Cr.S.A.)

${ }^{46}$ That's really a bald! They want to kill me! (t.a. Cr.S.A.)
} 
un'ape ne' giorni d'aprile, full of airs, imitating the rich ornately song of castrated in a type of opera, seria, Dandini tells of many attempts to find un boccon squisito $^{47}$ among so many beautiful girls, but he did not like any of them.

The flattery of the girls is obvious; they are trying hard to prove their charm and grace. As usual, Clorinda reacts first, but the replica: prence is interrupted by Tisbe (decendent leap of quart), the result being a suspension given by pauses. After Dandini flatters them by calling them: graziosa and vezzosa, on a radical change of tempo (Vivace, in pianissimo) he is very amused at the thought of the tragedy that would replace the comedy when the two fatuous find that they are flirting with a valet (Ma al finir della nostra commedia, che tragedia qui nascer dovrà $\left.{ }^{48}\right)$. His sly replies were not without effect, for the sisters' aparte express the certainty and satisfaction that the prince was taken: Ei mi guarda, sospira, delira, non v'è dubbio: è mio schiavo di già ${ }^{49}$.

At the same time Don Ramiro is subjugated by Cenerentola (identical exposure to the sisters, repeated note, same rhythmic pattern, also in the form of aparte). Don Magnifico carefully observes Dandini and feels that he is already in love with one of his daughters, and his pride and happiness as the parent of the future princess is being played musically by the ascending movement (octave): $e$ già cotto, stracotto, spolpato ${ }^{50}$.

E.g., 10 (G. Rossini - La Cenerentola, G. Ricordi \& C. Editors - Stampatori, Milano, 1997, act I, Cavatina Dandini: Come un'ape ne giorni d'aprile, p. 81, ms. 97-105):

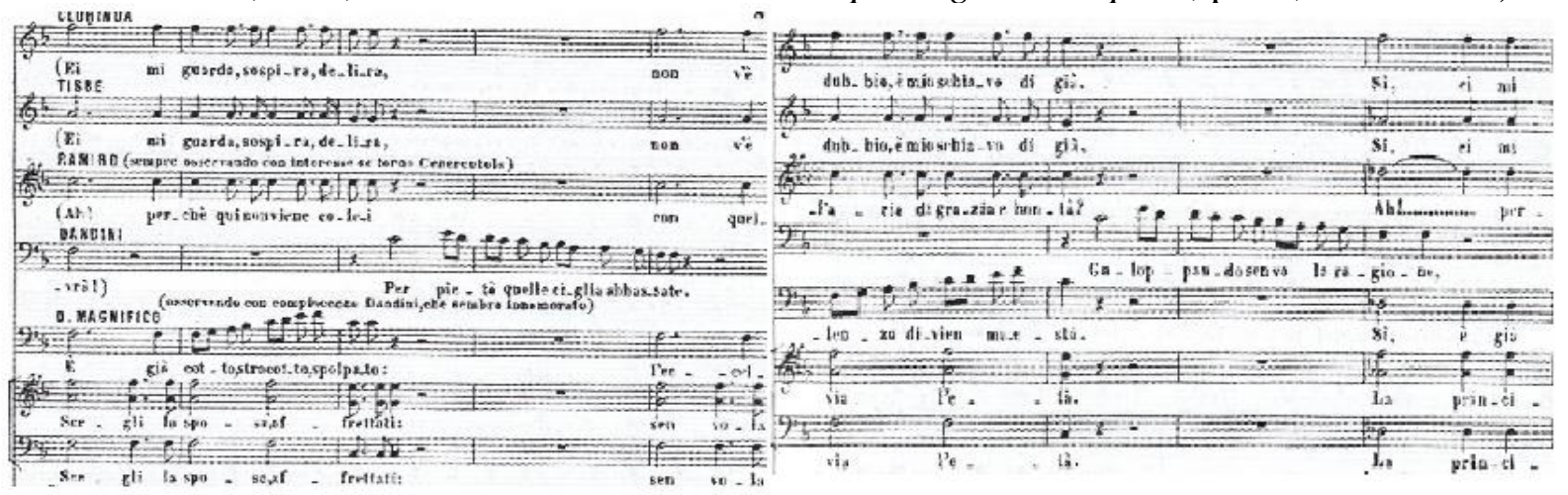

Tisbe and Clorinda separately express the joy of being chosen by the prince, and Don Ramiro and Dandini have great fun on account of the farce before them.

E.g. 11 (G. Rossini - La Cenerentola, G. Ricordi \& C. Editors - Stampatori, Milano, 1997, act I, Cavatina Dandini: Come un'ape ne giorni d'aprile, p. 83, ms. 118-125):

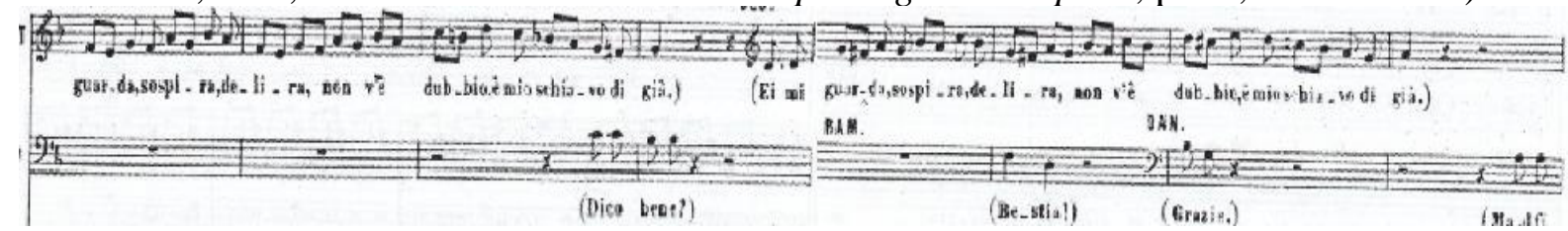

The orchestral accompaniment acts as a melodic support in the medium and accute registry and doubles the voices of the soloists, while the low register (via the pedals on the $F, G$ and $C$ ) perform the shift from one tone to another ( $F$ major, $G$ minor, $F$ major). The appearance of minor tones within the overall cheerfulness is a subtle warning, which provides for the disappointment of the

\footnotetext{
${ }^{47}$ A tasty piece (t.a. Cr.S.A.)

${ }^{48}$ But at the end of our comedy, what a tragedy will arise!(t.a. Cr.S.A.)

${ }^{49}$ He is looking at me, he's sighing, he's delirious, I have no doubt: he's already my slave (t.a. Cr.S.A.)

${ }^{50} \mathrm{He}$ 's already cooked, made stew, destroyed by so much love (t.a. Cr.S.A.)
} 
sisters now of finding out the truth. The prevailing nuance is forte, with the involvement of the entire orchestral and vocal assembly existing at present on the stage. Dandini's cadence describes the barely mastered laughter, with the composer supporting the soloist by the absence of the orchestra (only a chord), to facilitate the supple and expressive execution of colors.

E.g. 12 (G. Rossini - La Cenerentola, G. Ricordi \& C. Editors - Stampatori, Milano, 1997, act I, Cavatina Dandini: Come un'ape ne giorni d'aprile, p. 87, ms. 155-159):

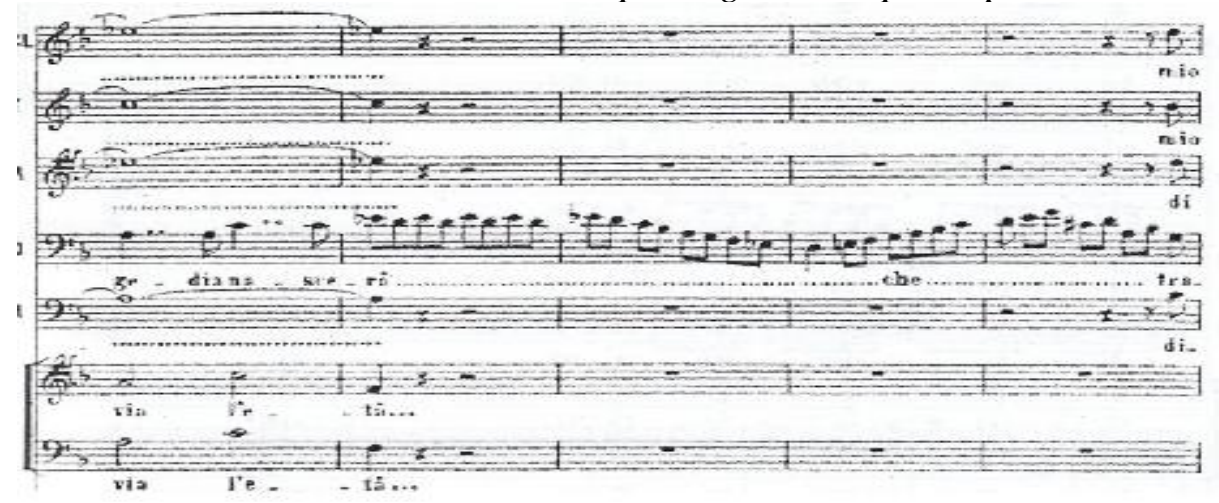

The end of the first act starts with an alert duet between Dandini and Don Ramiro, in which the valet expresses his opinion on the characters of the girls of the baron: un misto d'insolenza, di capricci e vanita ${ }^{51}$. Don Ramiro cannot understand why Alidoro, his wise friend who always advised him well, told him that the chosen one should be one of Don Magnifico's girls (Alidoro mi diceva che una figlia del Barone ${ }^{52}$ ). The two contenders make their way, desperately searching for the prince who accompanied them to the palace and then disappeared (Vivace, with a chord of $\mathrm{G}$ major followed by two motives with a melodic frent, descending movement). E.g., 13 (G. Rossini - La Cenerentola, G. Ricordi \& C. Editors Stampatori, Milano, 1997, act I, Finale primo, p. 162, ms. 1-4):

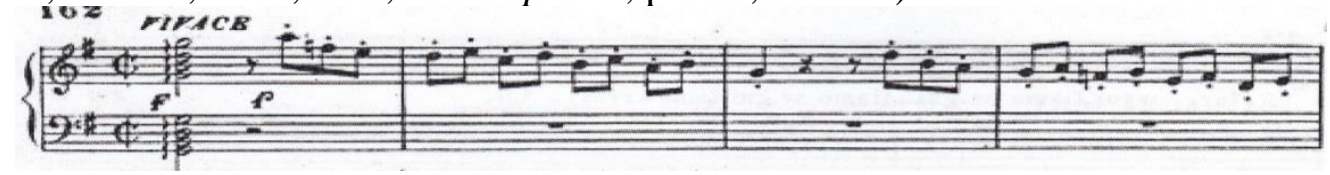

Dandini warned them that he could marry only one of the sisters, arousing jealousy and uncertainy, then he suggested that the latter should become the wife of his friend, the squire. Clorinda flatly refuses the offer, as did Tisbe, arguing that such a marriage would be below their social level. The fragment is built on the superposition of melodic lines at a quart and descending quintle interval with the same text and rhythm, and the orchestra supports the musical deployment through bas Alberti and accents on the first and third beats.

E.g., 14 (G. Rossini - La Cenerentola, G. Ricordi \& C. Editors - Stampatori, Milano, 1997, act I, Finale primo, p. 164, ms. 44-47):

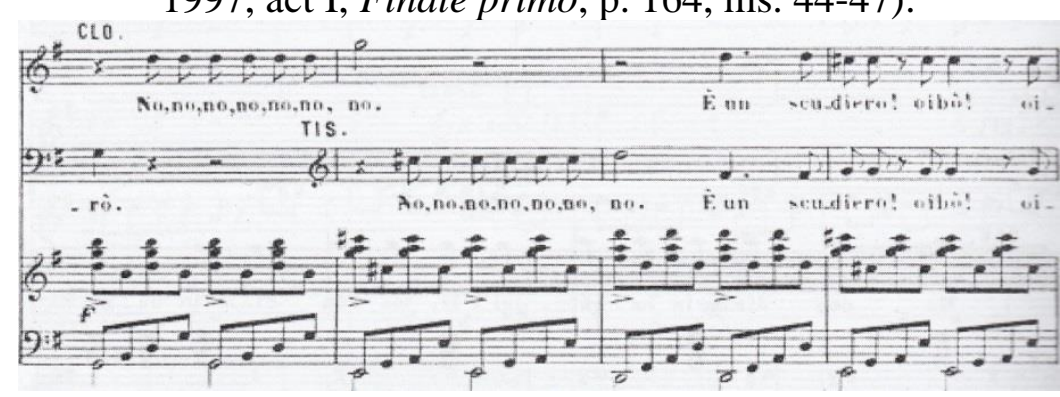

\footnotetext{
${ }^{51}$ A mixture of insolence, whims and vanity (t.a. Cr.S.A.)

${ }^{52}$ Alidoro told me about one of the Baron's daughters (t.a. Cr.S.A.)
} 
Although Don Ramino (valet) looks like calm and obedient, he attracts the disdain of Clorinda, who does not want to marry with a simple squire, without a material situation or important position at the palace.

E.g., 15 (G. Rossini - La Cenerentola, G. Ricordi \& C. Editors - Stampatori, Milano, 1997, act I, Finale primo, p. 164, ms. 51-55):

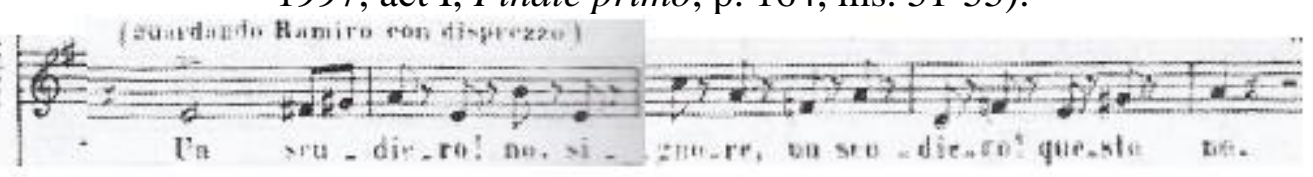

Even if Don Ramiro assures them that he will be a good and loving husband, he faces firm rejection, marked by repeated (equal eights) sounds that reveal vanity and despair. The gradual melody movement of men (eights) is taken over by Clorinda and Tisbe on the same notes, with identical accompaniment, the quartet turning into a scene of tension and rage for sisters, and of leisure and amusement for Ramiro and Dandini.

E.g., 16 (G. Rossini - La Cenerentola, G. Ricordi \& C. Editors - Stampatori, Milano, 1997, act I, Finale primo, p. 166, ms. 75-82):

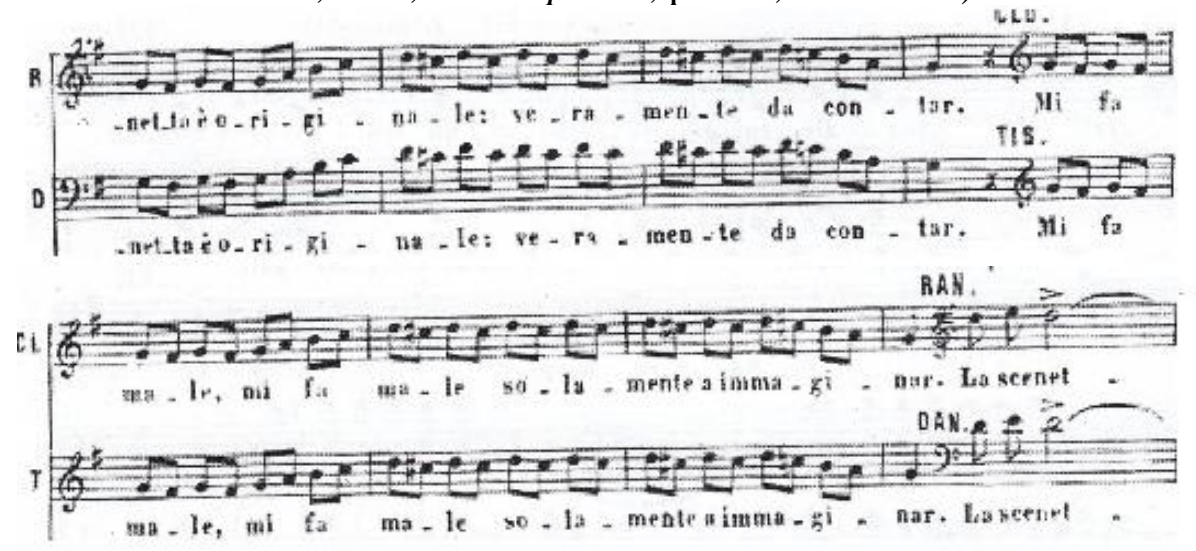

Gradually, three sound planes are distinguished: the sisters take the answer from one to the other, Don Ramiro shows his surprise, and Dandini expresses his fun.

E.g., 17 (G. Rossini - La Cenerentola, G. Ricordi \& C. Editors - Stampatori, Milano, 1997, act I, Finale primo, p. 167, ms. 87-94):

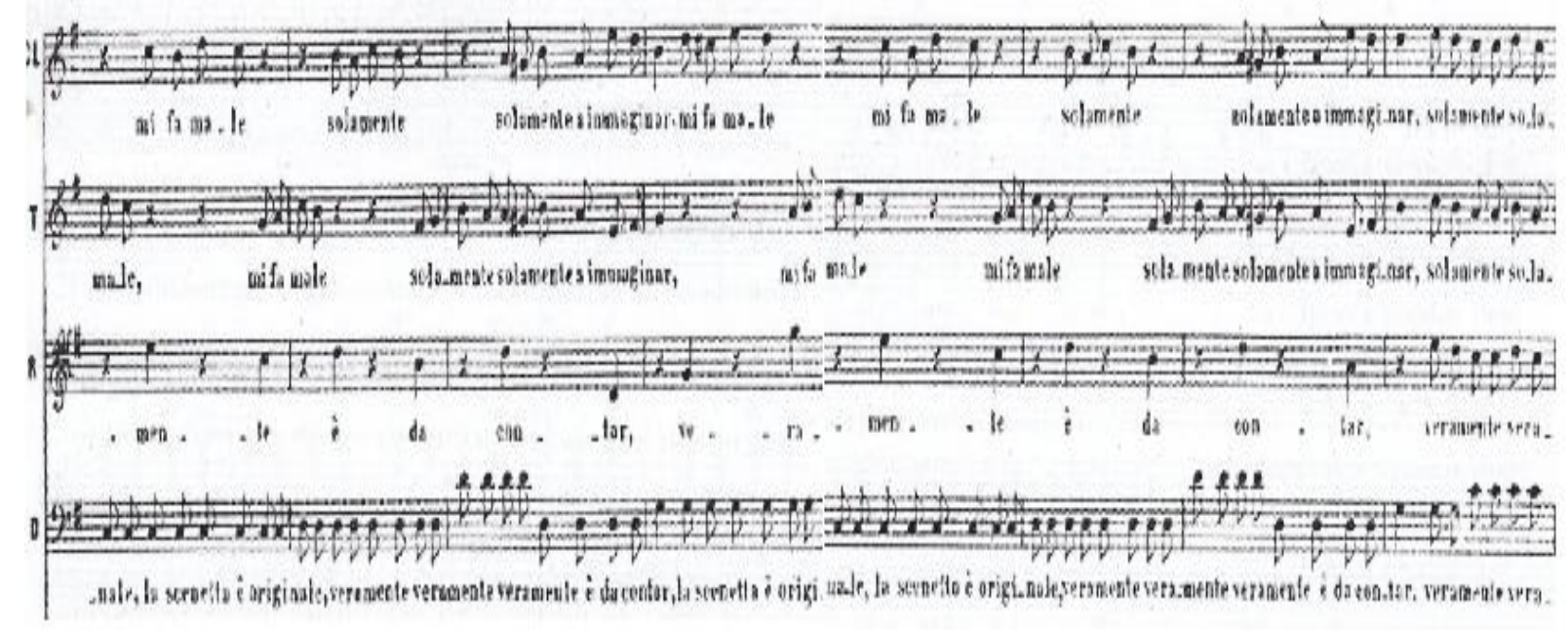

The four voices meet in a homophonic manner toward the end, on an accompaniament doubled with the superior voices of the orchestra and bas Alberti (in grave). The last four measures of the orchestra are preparing the intervention of the men's choir and Alidoro's replies that announce the presence of an unknown at bal (Moderato, a piacere). 
E.g., 18 (G. Rossini - La Cenerentola, G. Ricordi \& C. Editors - Stampatori, Milano, 1997, act I, Finale primo, p. 170, ms. 129-133):

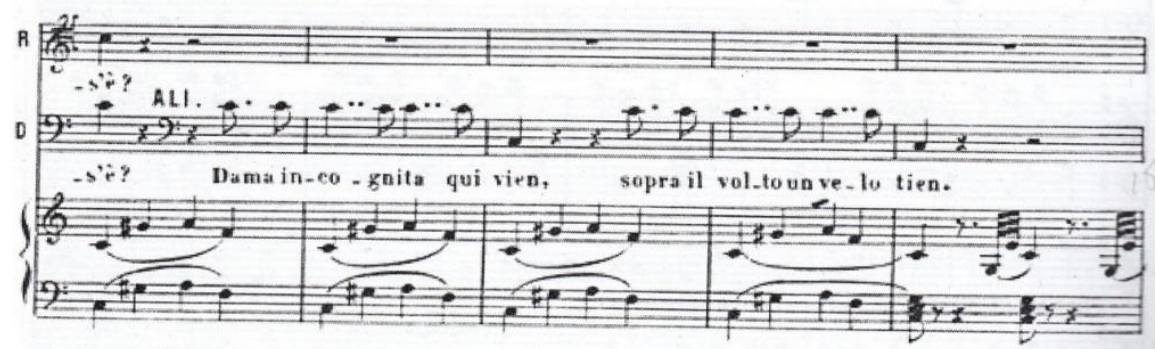

The mystery is amplified by the replica of the sisters (sotto voce, short rhythmic and melodic cells with restricted ambitus) which render the panic, the jealousy, and the envy toward the new claimant to the prince's hand.

E.g., 19 (G. Rossini - La Cenerentola, G. Ricordi \& C. Editors - Stampatori, Milano, 1997, act I, Finale primo, p. 172-173, ms. 161-164):

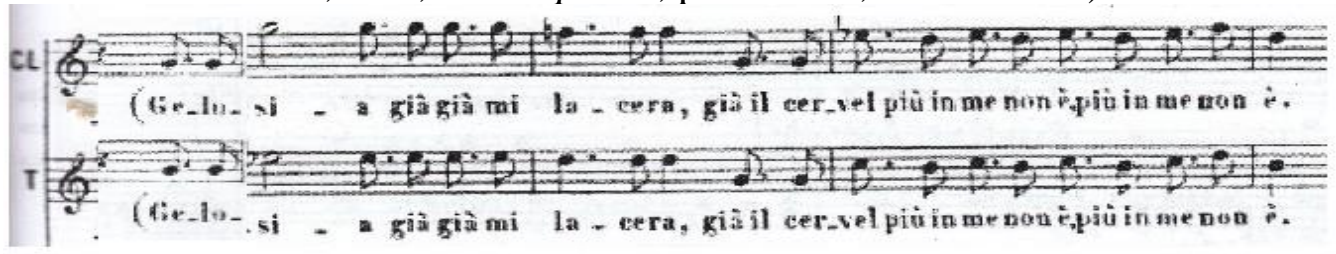

The Aparte of the sisters (piano, on short and dotted values) shows the disturbance caused by the appearance of the new character, but also the hope that the unknown cannot be more beautiful than them. Discovering the resemblance to the stepsister, their stupefaction is rendered by a break of eights with prolonged crown point. Again, Clorinda is the first bouncing back (descending melodic movement, large jumps between the intervals with fiorituri and embroidery), but the musical phrase is interrupted and segmented by breakes of sixteenths and short rhythmic and melodic cells that suggest the sensation of choking and fainting. Don Ramiro's joy, recognizing the girl he had fallen in love at Don Magnifico's house, is described by a rich ornated passage. The way in which the omophone structures in Allegro and Vivace are presented recalls the end of the second act of the opera $\mathrm{Il}$ Barbiere di Siviglia. Rossini builds the fragment with low values of notes (eights in general), gradual, ascending or descending melodic movement, a rich palette of nuances (from fortissimo to pianissimo) and an accompaniment that harmoniously supports the entire voice speech.

\section{The sextet and the final ensemble}

The famous sextet in the second act: Siete voi? is written in a Maestoso characterizing the solemnity of the moment and taking place after the prince reveals his identitty. The short phrases: Quel sorpresa! and Che sara! put in question the perfect (rhythmic) overlapping of voices. Over the elements of the chord of $E$ bemol major (filled in by passage notes), Dandini starts a musical phrase which will be taken over polyphonically by Don Ramiro, Cenerentola and Don Magnifico. Toward the end, the polyphony turns into omophony, with all voices singing the same melodic line and text on a chord of E bemol major. The rhythm and melodic counter-position appears in Clorinda and Tisbe, which shows a repeated melody line with a dotted line. 
E.g. 20 (G. Rossini - La Cenerentola, G. Ricordi \& C. Editors - Stampatori, Milano, 1997, act II, Sestetto: Siete voi?, p. 286, ms. 28-29):

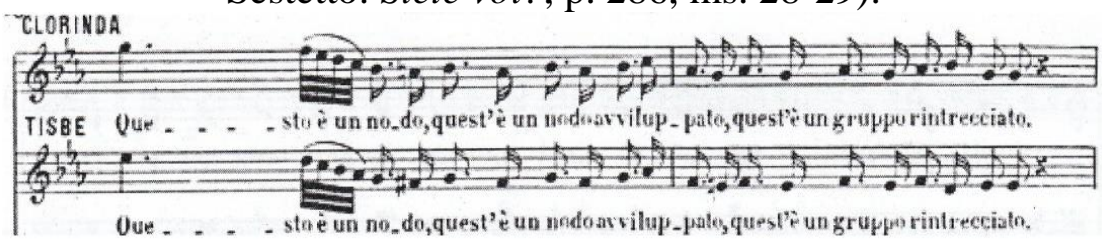

The variations in other voices are counterbalanced by the taking of the initial sentence (sisters): Questo e'un nodo avviluppato, quest'e un gruppo rintrecciato $^{53}$. The beauty and comic of the situation are derived from the literary text and the exaggeration of double consonants: avviluppato, rintrecciato, sviluppa, inviluppa, sgruppa, ragruppa, the stupefaction being translated by a short reason of a bel-canto character that occurs in turn in all voices imposing virtuosity, which valoralizes the vocal technique.

E.g. 21 (G. Rossini - La Cenerentola, G. Ricordi \& C. Editors - Stampatori, Milano, 1997, act II, Sestetto: Siete voi?, p. 287-288, ms. 32-39):
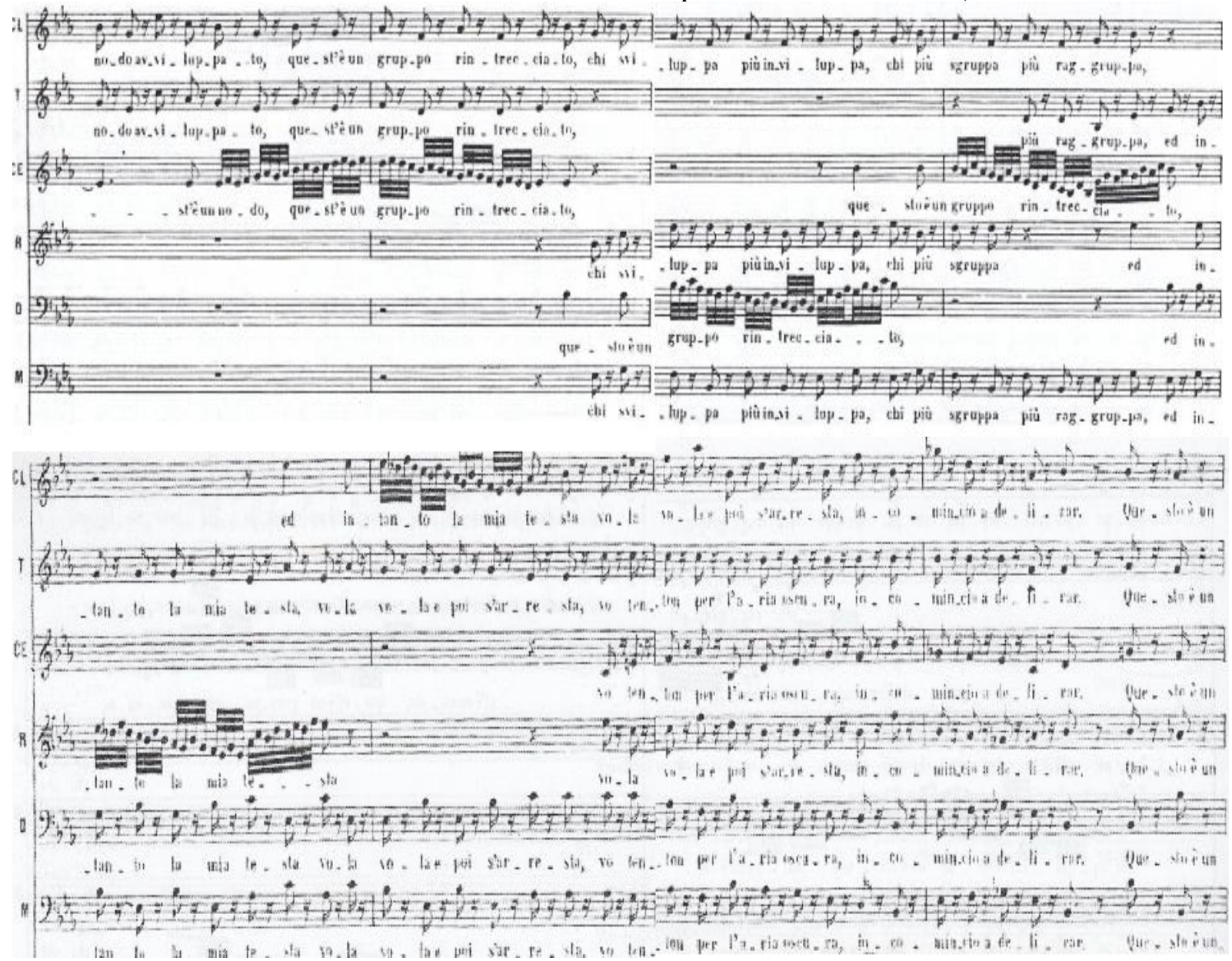

After a crowned pause, the Allegro indication and the intervention of Clorinda render the ugly, malicious, and low feature of the character. Donna sciocca, alma di fango ${ }^{54}$.

E.g. 22 (G. Rossini - La Cenerentola, G. Ricordi \& C. Editors - Stampatori, Milano, 1997, act II, Sestetto: Siete voi ?, p. 297, ms. 66-70):

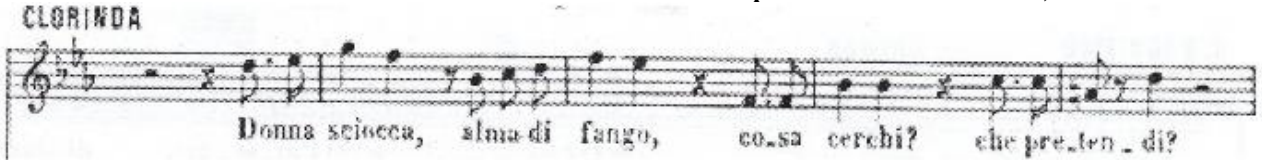

\footnotetext{
${ }^{53}$ This is a twisted knot, this is a confused group (t.a. Cr.S.A.)

${ }^{54}$ Vacuous woman, muddy soul (t.a. Cr.S.A.)
} 
Over the text: fra noi gente d'alto rango, l'arrestarsi è inciviltà" 55 the rhythmic (eights) and the melodic structure reveal the presence of a evil being, with traces of lure, and no trace of nobility, as Clorinda claims to be.

E.g. 23 (G. Rossini - La Cenerentola, G. Ricordi \& C. Editors - Stampatori, Milano, 1997, act II, Sestetto: Siete voi ?, p. 298, ms. 74-80):

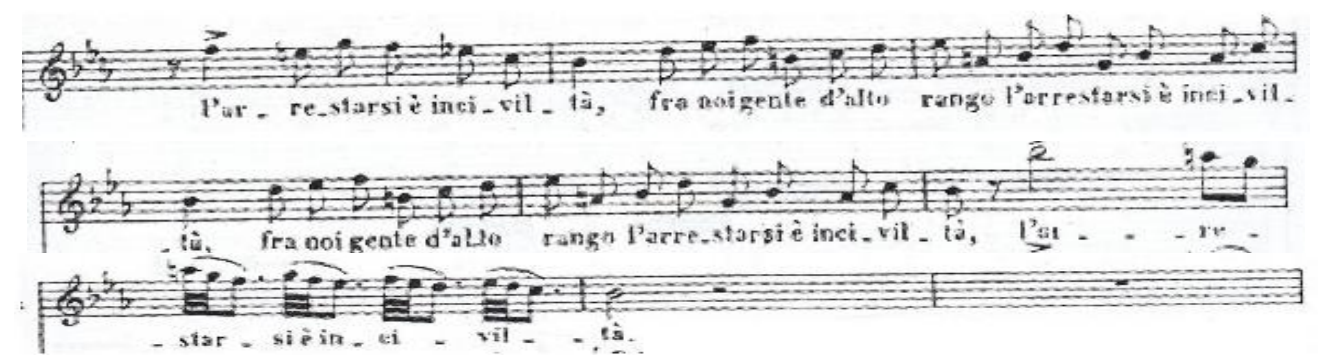

The contrast of nuances (piano-forte) reveals the inner kneading of Clorinda (unbridled anger and hate), and the orchestra doubles the solistic line with a dotted accompaniment that establishes harmonious structures ( $B$ bemol major). Don Magnifico takes up the melody line from his daughter who was overtaken by the same feelings and insulted Angelina: Serva audace, e chi t'insegna di star qui fra tanti eroi? Va in cucina serva indegna ${ }^{56}$; The prince expresses his anger against the attitude and insults addressed to Cenerentola (colei che adoro ${ }^{57}$ ); Dandini looks at the show, having fun of the way the prince sets the negative characters to the point of respect. The replies of the sisters: son di gelo ${ }^{58}$ and ma una serva... ${ }^{59}$ show once again the hate against the one they considered a "nothing," but which succeeded to seize the prince's heart, to which they coved. The words of Angelina filled with nobleness (Andantino, in a character close to the style of the opera seria) are in contrast with the words of the sisters, culminating with: oh, che rabbia che mi fa! $^{60}$.

E.g. 24 (G. Rossini - La Cenerentola, G. Ricordi \& C. Editors - Stampatori, Milano, 1997, act II, Sestetto: Siete voi ?, p. 304, ms. 163-165):

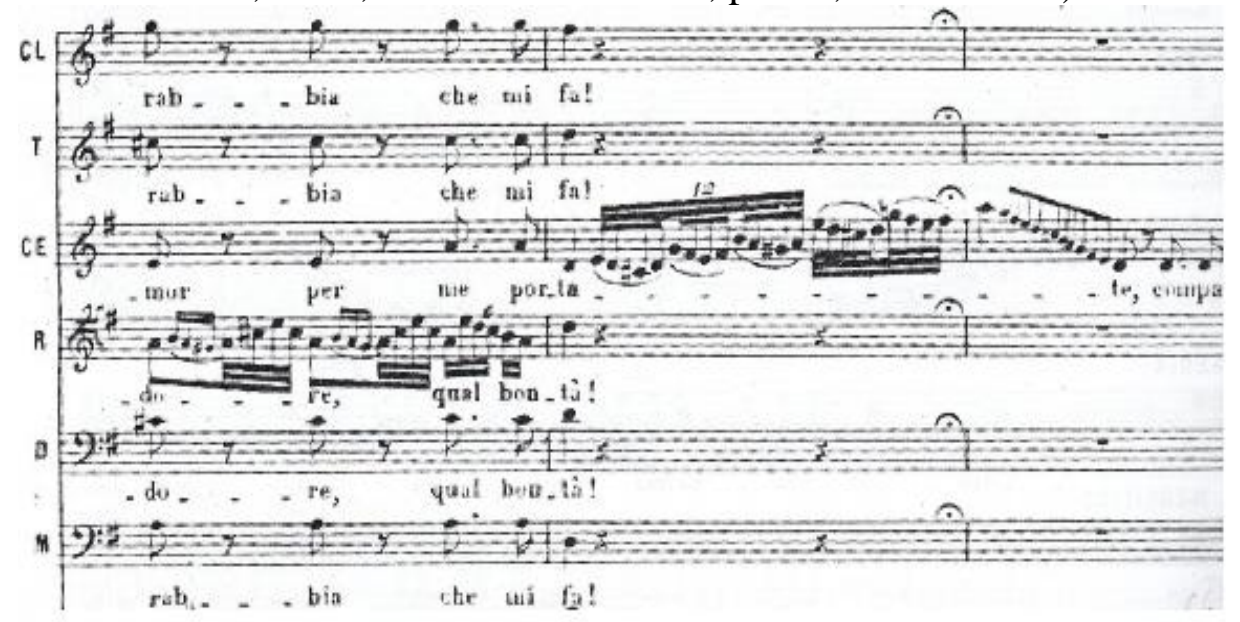

The desire of the prince to marry Cenerentola causes a real crisis of both contenders and their father. The precipitated replies (repeated sound, with equal

\footnotetext{
${ }^{55}$ Among us, the high-ranking people, stop this rude (t.a. Cr.S.A.)

${ }^{56}$ Daring servant, who allowed you to stay among prominent citizens? Go in the kitchen undignified servant (t.a. Cr.S.A.).

${ }^{57}$ The one that I adore (t.a. Cr.S.A.)

${ }^{58}$ I am made of ice (t.a. Cr.S.A.)

${ }^{59}$ But a servant... (t.a. Cr.S.A.)

${ }^{60} \mathrm{Ah}$, it makes me feel so angry! (t.a. Cr.S.A.)
} 
values) sound like a hammer when the three characters join their forces to strengthen their message: Dirà per ridere. Non vedi che ti burlano ${ }^{61}$. The first reply starts from piano, but along the way there is a crescendo to forte, which shows the attempt to make Cenerentola understand (if not willingly, then by force) that the prince mocked at her.

At the end of the sextet (Vivace), Tisbe sings in unison with his sister, even though from the point of view of the voice the voice passage poses more problems to the mezzo voice. The replies: quello freme, questo fiotta chi minaccia, chi sospira $^{62}$ find their antonyms in the happiness of Cenerentola: É un inganno! Ah! se mi desto, che improvviso cangiamento! ${ }^{63}$.

E.g. 25 (G. Rossini - La Cenerentola, G. Ricordi \& C. Editors - Stampatori, Milano, 1997, act II, Sestetto: Siete voi ?, p. 312-313, ms. 272-283):

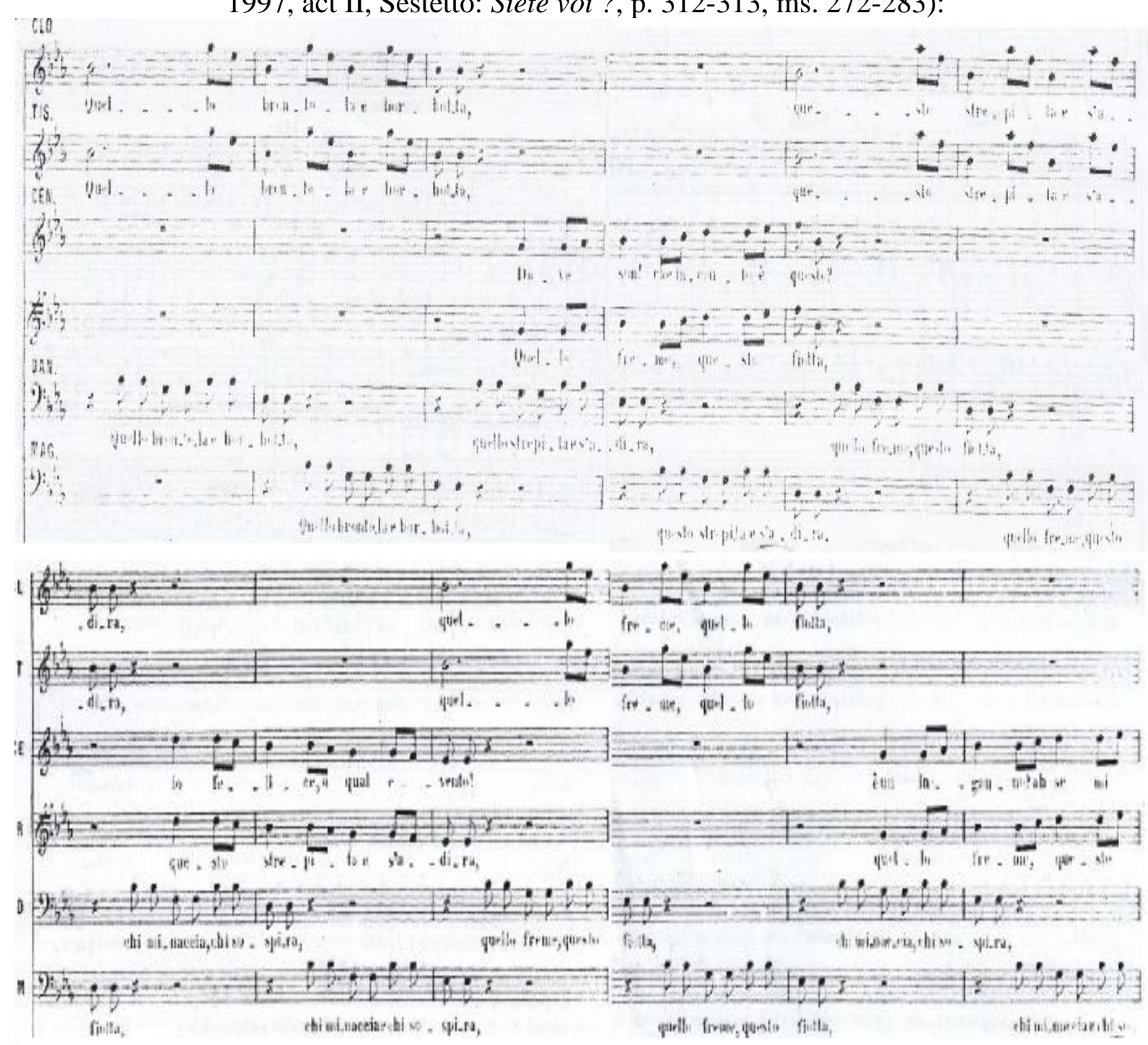

The following voice color passage is one of the most difficult moments of the work, as the overlapping of the four voices must be perfect on the same syllables: quello brontola e borbotta, questo strepita e s'adira, va a finir che a'pazzarelli ci dovanno trascinar ${ }^{64}$.

\footnotetext{
${ }^{61}$ He says it to laugh. Don't you see that he is mocking at you? (t.a. Cr.S.A.)

62 One stirs, one breakes out, threatens, moans (t.a. Cr.S.A.)

${ }^{63}$ That's an outrage! Ah! If I wake up... what a sudden change! (t.a. Cr.S.A.)

64 One mumbles and hounds, another screams and is furious at the top, will end up by getting mad and we will get him out (t.a. Cr.S.A.)
} 
E.g. 26 (G. Rossini - La Cenerentola, G. Ricordi \& C. Editors - Stampatori, Milano, 1997, act II, Sestetto: Siete voi ?, p. 320-321, ms. 320-332):

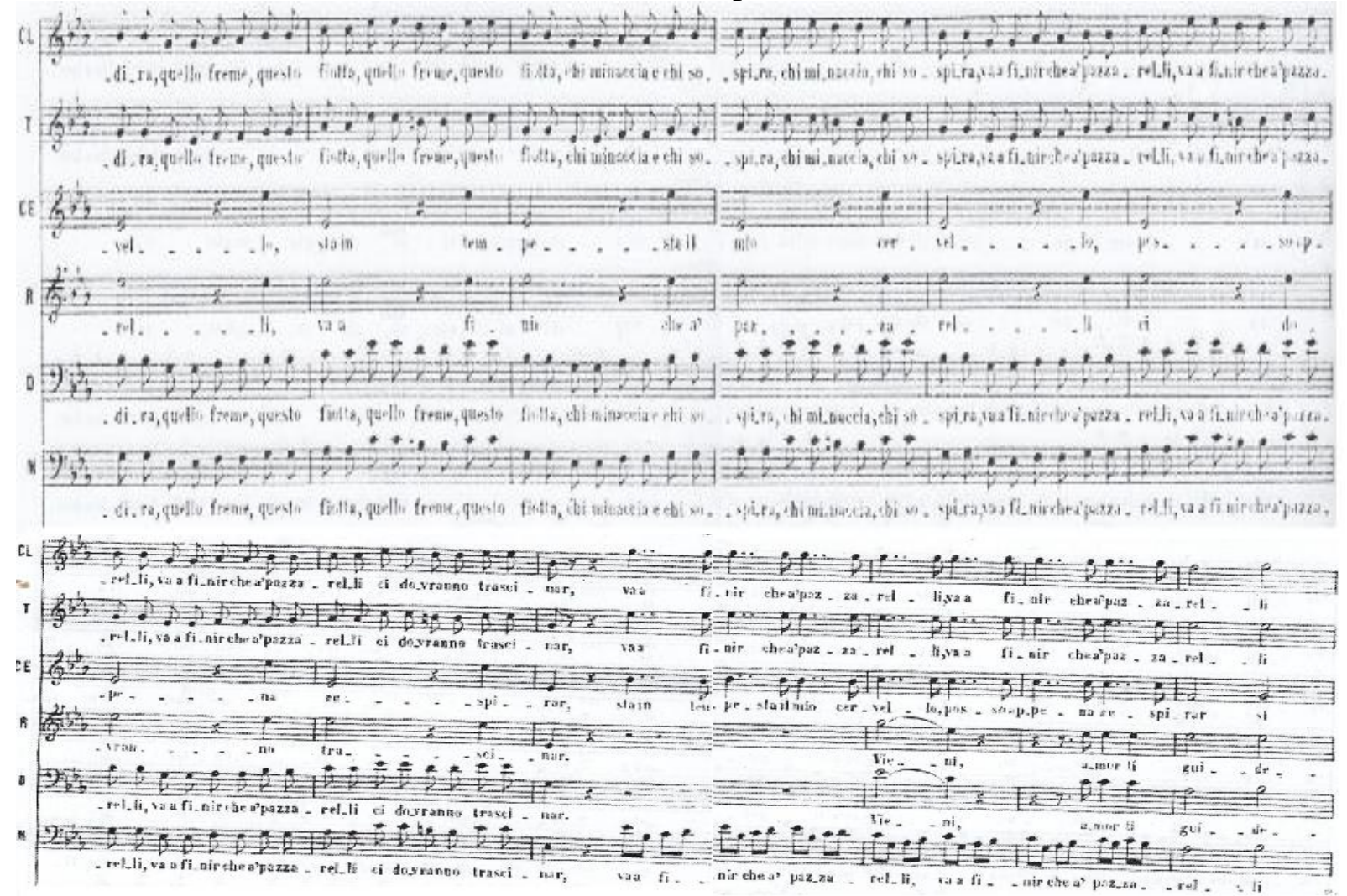

In the final ensemble of the opera, Angelina forgives her father and sisters, to their great stupefaction; they are filled with admiration for the first time, accepting and finally understanding the purpose of goodness, mercy, and unconditional love. For the first time, the melody line of the sisters Clorinda and Tisbe took on nobleness: Degna del tron tu $s e i^{65}$. The feelings of satisfaction and happiness are expressed in the nuance of forte, on an accompaniament of harmonious support ( $G$ major). The response of Cenerentola is in the original tone (E major), as well as the message of peace and happiness cessa alfin di sospirar ${ }^{66}$ (soloists and choir) in sotto voce - which by a crescendo lead to fortissimo in the end.

E.g., 27 (G. Rossini - La Cenerentola, G. Ricordi \& C. Editors - Stampatori, Milano, 1997, act II, Coro, Scena e Rondo Finale, p. 333, ms. 93-99):

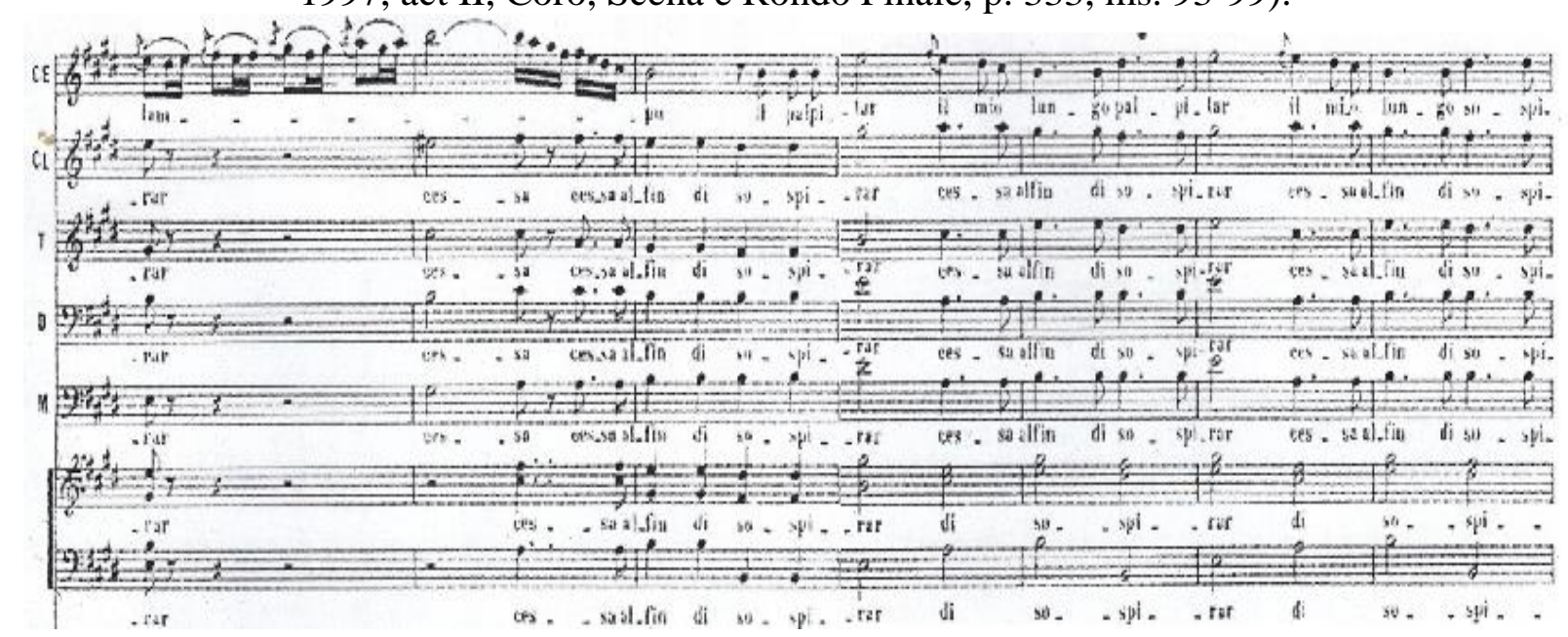

${ }^{65}$ You are worthy of the throne (t.a. Cr.S.A.)

${ }^{66}$ The suffering is over (t.a. Cr.S.A.) 
The work ends optimistically, in E major, with an orchestral coda that renders the reconciliation and the satisfaction of all the characters. Rossini does not want Tisbe and Clorinda to remain negative characters, but to turn them into gentle beings who recognize the merits of Cinderella and prove that they have finally understood the morals: the good always wins.

\section{Conclusions}

Either lyric dramas, or comic operas, the works are drawn by the same enthusiasm which is found in the rhythmic acceleration and in the so typical crescendos. Everything and everyone seems to forever be running in these works, composed in a haste, somewhat sloppy. The spectator does not have time to get bored, the arias being vivid with filler passages which inspire much joy and youthfulness. Rossini's vision on the new Italian opera is in key with his entire behaviour in the first half of this life. Young and teeming musician, he is not an exponent of lightness and routine. On the contrary, he shows very quickly how capable he is to be an innovator.

\section{References}

1. Buga, Ana și Sârbu, 1999, Cristina Maria 4 secole de teatru muzical, București

2. Câmpeanu, Liviu, 1975, Elemente de estetică vocală, Editura Interferenţe, Bucureşti

3. Constantinescu, Grigore și Caraman-Fotea, Daniela, 1971, Ghid de operă, București

4. de Uscătescu, Consuelo Rubio, 1989, Arta cântului, Editura Muzicală, Bucureşti

5. Pascu, George şi Boţocan, Melania, 1995, Popasuri în istoria muzicii, Editura Spiru Haret, Iaşi

6. Pinghireac, Georgeta, 2003, Simboluri estetice ale vocii de soprană, Editura Universitaţii Naţionale de Muzică, Bucureşti

7. Rossini, Gioacchino - La Cenerentola, Milan: G. Ricordi, n.d., New York: Edwin F. Kalmus, n.d. (după 1933). Catalog A 3031

8. Rossini, Gioacchino - La Cenerentola, Leipzig: Breitkopf \& Härtel, n.d.(ca.1820). Plate 3730

9. Sâmpetrean, Mircea Radu, 2007, Cunoaşterea vocii umane şi persuasiunea jocului scenic, MULTIMEDIAMusica, Cluj

10. Sbârcea, George, 1960, Rossini sau triumful operei bufe, Editura Muzicală, Bucureşti

11. Ștefănescu, Ioana, 2002, O istorie a muzicii universale, Vol. IV, București 